\title{
Bioelectricity Potential through Plant Microbial Fuel Cell System using by Cynodon dactylon (Dooba ghas)
}

Atit Kumar Jawre ${ }^{1}$, Priyanshi Chauhan ${ }^{2}$, Anket Patel $^{3}$, Hari Prasad Prajapti ${ }^{4}$, Sardul Singh Sandhu ${ }^{1, *}$

$$
\text { Research Scholar }{ }^{1} \text {, Student }{ }^{2,3,4} \text { Professor }^{1^{*}}
$$

1,3, ${ }^{*}$ Department of Biological Science, Rani Durgawati University, Jabalpur (M.P.), 482001,

${ }^{2}$ Department of Biotechnology, Amity University (Rajasthan), 303002

4, Bio-design Innovation Center, Rani Durgawati University, Jabalpur (M.P.), 482001,

*Correspondence: $\underline{\text { ssandhu@ } @ \text { rediffmail.com }}$

\begin{abstract}
Abstarct
In these times electricity is big trouble of problem facing by the world. Therefore, there is necessitating for the property basis of energy that is employed for as bio-electricity. Many of the scientists and researchers are trying to find out the sustainable energy generates with the help of plant microbial fuel cell. Plant microbial fuel cell (P-MFCs) could be feasibility technology approach of bio-electricity generation which is mutualism interaction of the plants along with their rhizospheric bacteria. In the present study, Plant-microbial fuel cell was observed in grass $e$-table evaluated in term of bioelectricity generation from Cynodon dactylon (Dooba Ghas). This e-table was connected with electrode and different condition (physical and chemical) to detect the change in bioelectric potential. It was found that maximum voltage generated among all the conditions was $4.24 \pm 2 \mathrm{~V}$ at 15 days by using Cynodon dactylon through P-MFCs. The potential difference generated through P-MFCs was measured using a multimeter. The generation of bioelectricity was observed under different conditions like exposure to light and shade condition measured for voltage was found to be significantly different parameters. The maximum recorded under light and shade conditions were $3.82 \pm 2 \mathrm{~V}$ and $4.25 \pm 2 \mathrm{~V}$ respectively at 15 days of incubation.
\end{abstract}

Key-words: P-MFCs; Cynodon dactylon; energy; bioelectric potential; electricity generation.

\section{Introduction}

Now day's energy has highly demand for production of energy it's required a large amount of non-renewable resources. These are resources like coal, petrol and wooden etc. causes the 
deleterious effects on the environment. Several type of renewable energy is used for production of electricity by metabolic activity of microbes to turn the organic compounds to inorganic compound. During this process are microbes produced electrons as a byproduct from living plant through photosynthesis. P-MFCs is promising sustainable technology by using Cynodon dactylon as substrates, which can be used as chemical energy to convert into electrical energy by the process of bio-electrochemical system. This technology is less expensive and easy methods for production of electricity everywhere through Plant-Microbial fuel cell system. This is new trends technology development promoting no emits pollutant energy sources states that $60 \%$ of non-renewable energy sources will be changed with wind and solar being the most sensible energy production from 2030. These technologies are the maintaining and conservation of biodiversity for the production of power and preservation. India is the seven largest countries present in the world which is utilized the electricity consistent with capita $1010 \mathrm{kWh}$. At the same time, $4.7 \%$ of the geographical landmass in India is wetlands which are not utilized [1].

Plant-microbial fuel cell (PMFCs) is referred to as bio-batteries or biophotovoltaic device that are electricity produced from organic matter contain in the living plants. These are organic compound $\left(\mathrm{C}_{6} \mathrm{H}_{12} \mathrm{O}_{6}\right)$ generated by the plant which is process of photosynthesis that is a part of plant's growth and development. But, they are large amount of released out of the plant roots into the soil. Bacteria are presents surrounding the rhizospheric soil which is breakdown the organic compounds releases the electrons. These types of electrons are arrested by conductive electrodes inside the grass E-table completed the circuits thus producing of electricity using by plantmicrobial fuel cell system. The schematic diagram representation of microbial fuel cell including of plants describe as shown in Figure 1 [2]. Several of plant species have been tried in different models for the produced electricity with the help of PMFCs system. For example, Bryophytes (Mosses) are the small flowerless plants rising in dense clumps in shady and damp areas belong to phylum Bryophyta. They have no presence of true roots is also known as non-vascular plants. Many of researchers are finding out of mosses that are able to produce electricity with the help of biological material so called as biophotovoltaic device or bio-electrochemical system. This innovation has given the requirements by photosynthetic ability of mosses towards producing usable energy or stimulating a small light or a digital device. Moss table demonstrates the practical use and future prospects of biological photovoltaic through generates electricity in a lamp. Moss table is a circular table of $1 \mathrm{~m}$ diameter and $1.2 \mathrm{~m}$ high and produce of electricity about 520 Joules 
of energy per day. Potential difference obtains of each pot was measured in 0.4-0.6 volts and also currents was measured in each pots values of 5-10 $\mu \mathrm{A}[3]$.

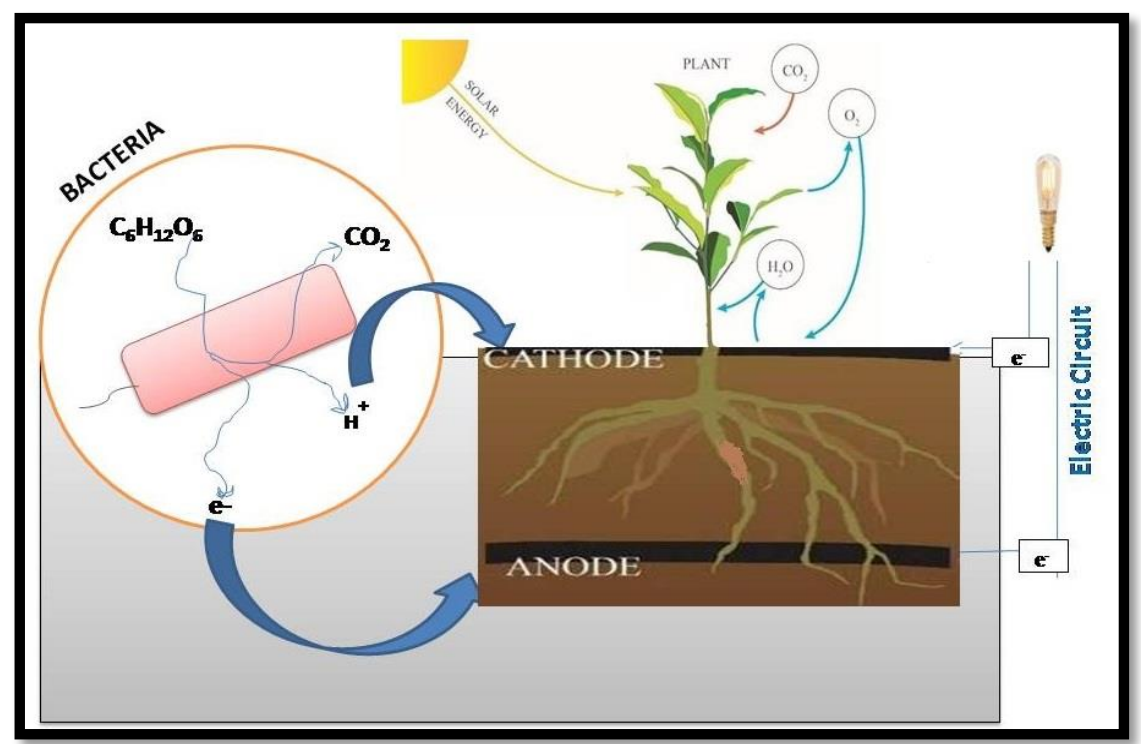

Figure 1. Schematics diagram representation of PMFCs [2].

Similarly, Sediment type of power output associated with the living plant microbial fuel cell system is construct like, downward of anode regions, dimension of electrodes and relatively put away of anode and cathode to be studied as construct in a paddy PMFCs. In this system was constructed the first anode inserted to be plunged $2-5 \mathrm{~cm}$ into the soil other than the cathode was not here on the surface of the water. Although, the cathode dipped into the soil through paddy PMFCs was determined to release oxygen by plant roots and thus providing a reduced amount of distance between two electrodes regions. These factors affect the analyzed for power output through paddy-PMFCs. The energy output of $5 \mathrm{~cm}$ dipped anode was almost three times the energy output of the $2 \mathrm{~cm}$ depth anode. In addition, high energy efficiency is obtained for a microbial fuel cell system, the anode was placed $5 \mathrm{~cm}$ in soil. Since, it can be proficient in these types of results to facilitate recognition of the appropriate anodic zone is necessary to ensure that the anoxic condition and consumption of the discharge carbon through microbes in P-MFCs are present. Similarity, the anode distance from the plant roots area can change alternating techniques for production of electricity. During paddy- P-MFCs, this research exposed the results of anode and cathode for aspects in achievement and that research observed in anode region which is the limiting factor until the microbial community has adjusted in the long run and reduces the effectiveness of the P-MFCs system in cathode efficiency [4]. 
Cynodon dactylon is a plant genus classified under the Poaceae family and it is generally grown into the soil salinity as a terrestrial plant that grass is found in India name is Dooba Grass, where it is abundant on roadsides and sports field. It could be damage itself recover rapidly. This is a very appealing turf grass in extreme warm condition, especially for those areas where its raise temperature and water tolerance shortage make it's easier to survive where grass to do. These type of grass edge is grey-green color which is shortly $2-15 \mathrm{~cm}(0.79-5.91$ inches) and edge is elongated rough that raised to stems are erect grow upright 1-30 $\mathrm{cm}(0.39-11.81$ inch). which is substantially flattened also typically purple in color which is made annually from a stem and growth takes up at temperatures above $15^{\circ} \mathrm{C}\left(59^{\circ} \mathrm{F}\right)$ with optimal growth between 24 and $37^{\circ} \mathrm{C}$ (75 and $99^{\circ} \mathrm{F}$ ); and this sort of grass become resting winter condition and turns brown color. This growth is nurtured by full sunlight and developed by full shade condition, e.g., close to tree trunks and thus providing a habitat for the development of microbes dependent on rhizodeposits as shows Figure 2 [5].

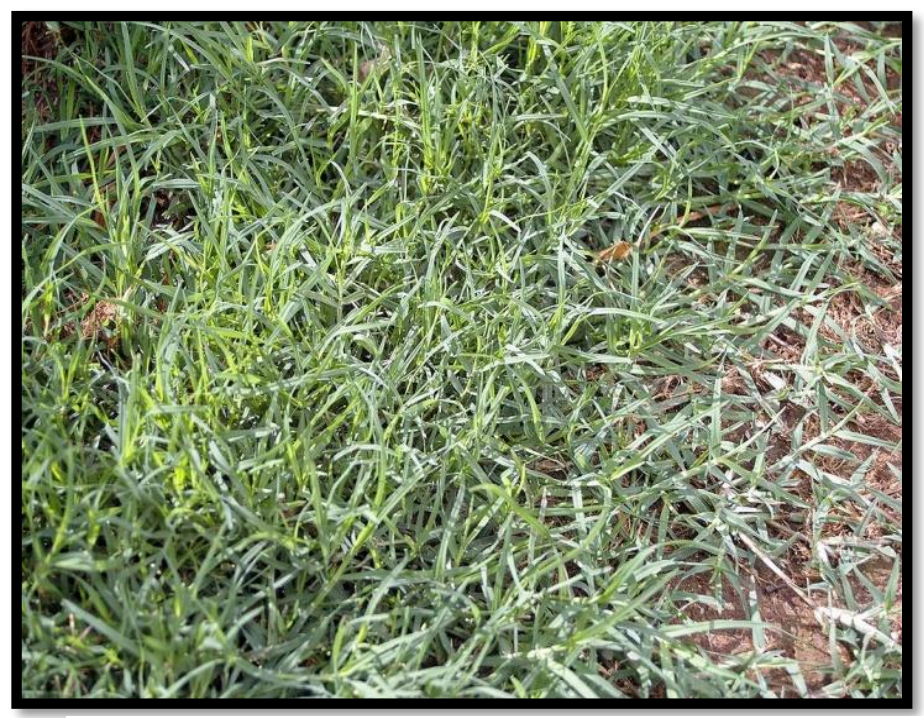

Figure 2. A Showing of Cynodon dactylon [5].

\subsection{Photosynthesis}

Photosynthesis is the methods of utilized by green plant and certain microbe for happens in chemical reaction which is energy take place inside the plants. This chemical energy converts into electrical energy during sunlight and discharges fuels. This arrange of chemical energy is performed by the molecule of carbohydrate such as sugar which is used as carbon dioxide and water close to the pigment of chlorophyll that makes glucose product and releases oxygen. Photosynthesis includes two types of process is anoxygenic photosynthesis and oxygenic 
photosynthesis. The overall process of anoxygenic and oxygenic photosynthesis are basically the same as, but the widely recognized is oxygenic photosynthesis due to plants, algae and cyanobacteria. An overall equation of photosynthesis as shown below [6]:

$$
6 \mathrm{CO}_{2}+12 \mathrm{H}_{2} \mathrm{O}
$$

A photosynthesis reaction takes place into two phages: first phase of light-dependent reactions which is supported on temperature-independent. Second phase of temperature-dependent reactions those are based on the light independent. The first of rate phase is called light reaction which can be improved by increasing light intensity other than temperature increases. Another rate phage referred to as dark reaction rate can be improved by increasing temperature although may not be enhanced by raising light intensity. However, commonly reducing agent used such as hydrogen and hydrogen sulfide for comparatively to water as sources of an electron [7].

In the present research work the variation recorded in the bioelectric potentials of electricity from Cynodon dactylon will be exposed. These studies are still very much in its beginning and not yet commercially feasible as such, but the concept of behind the reason is show assured in terms of both given green energy and spaces for generation of electricity which is used for the small electrical gadget generating such as laptops of desk lamps, but the future study we could find much better applications using by plant microbial fuel cell (P-MFCs) on the turning walls, roofs, yards and gardens into renewable sources for the generation of electricity. In this study following objectives are (1) Assessment of incorporated rhizospheric bacteria of Cynodon dactylon for bioelectric potential efficacy. (2) Evaluation compares the production of bio-electric potential from different physical and chemical condition.

\section{Materials and Methods}

\subsection{Plant Materials used in PMFCs}

This research was carried out with grass species Cynodon dactylon (seed) used in this experiment were online purchased from Farm seeds ${ }^{\mathrm{TM}}$ as described by [8]. Therefore, PMFCs device is technology will be eventually developed into another valuable tool and PMFCs system offer the prospect of an inexpensive light energy capture technology and primary energy production. 


\subsection{Construction of P-MFCs Set-up}

\subsubsection{Electrodes}

The copper plates and zinc rods were used to at the ends of cathode and anode also tightly fixed with the P-MFCs chamber containing of Cynodon dactylon. Theoretically, electrodes can be element of the reaction facilitated in a plant microbial fuel cell. Copper electrode was placed on top to better attract the electrons from the decomposition of organic material by bacteria. Copper and zinc electrodes were the two materials chosen because they have different electric potentials.

\subsubsection{Cathode Compartment}

The cathode compartments were preparing the zinc electrode, as a biocatalyst.

\subsubsection{Anode Compartment}

The anode compartment were inserted the Copper electrodes (anode chamber), with the wet Cynodon dactylon with soil added to it and making space between the soil and the wall of the plastic container around $2 \mathrm{~cm}$ to $2.5 \mathrm{~cm}$ to irrigate the plant.

\subsubsection{Assemble of P-MFCs}

This research work carried out by the plant microbial fuel cells constructs in containing the cathode and anode compartment assembly under ambient condition. In this experiment, the soil was collected from the Kasturi nursery, Jabalpur (M.P.) and well characterized as organic fertile soil. These are basics soil properties as shown in Table $\mathbf{1}$ [8]. The plastic pots were filled with organic fertile soil and Cynodon dactylon (seed) used acclimatized into the pots on the $5^{\text {th }}$ to $7^{\text {th }}$ day after germination. The P-MFCs setups consists of plastic pots, with dimensions of roughly 8.6 $\mathrm{cm} \times 10 \mathrm{~cm} \times 6.5 \mathrm{~cm}$ (length $\times$ width $\mathrm{x}$ height). Small pieces of plastic were inserted into the bottom of these plastic cartons to prevent leakage of water from the holes in the bottom. The cathodic compartments consist of the copper electrode, with not involved the proton exchange membrane. Which contain plant material on carbon fiber joined anodes zinc electrode. In this configuration, the photosynthetic vascular plant is utilized for feeding heterotrophic bacteria in the rhizosphere. At that point, those bacteria produced electrons that can be collected by an anode and circuits were completed. The voltage readings were taken from digital multimeter Figure 3 [9]. After a few days for the proper maintain growth and development of plants were added of plant growth regulators $[\mathbf{1 0}]$.

\subsection{Evaluation of bioelectric potential of Cynodon dactylon}

\subsubsection{Effect of Light and Shade Condition}


To observe the effect by light and shade condition on PMFCs all the pots were taken and one pot was taken exposed in direct sunlight 10 am to 5:30 per day for 15 days. Another pot was taken kept in the dark condition the same duration of time from 10 am to 5:30 per day for 15 days. Record the readings with the help of a multimeter.

\subsection{To formulate electrical Grass E-table harness electricity by using P-MFCs}

To formulate bioelectrical potential of grass E-table to harness electricity by using P-MFCs exploits the electrons and protons generate by photosynthesis and metabolic activity. The Cynodon dactylon and along with their rhizospheric bacteria material is placed inside one of electrodecontaining chambers. The two electrodes will be use anode and cathode, with the anode placed in contact with the rhizospheric bacteria. These bacteria during the degradation of organic compound that's release electrons that were first collected by the anode present in the soil. At the cathode, a reaction with a relatively high potential consumes electrons and creates a potential difference between the two electrodes. The electrical currents produce through an external circuit according to Bombelli, (2013) [2].

\subsection{Isolation of bacteria from rhizoids in anodic chamber of Cynodon dactylon}

In order to isolate the different microbial populations constituting the rhizospheric anodic P-MFCs biofilm, we scraped the electrode anode surface using a sterile utensil in $50 \mathrm{ml}$ of distilled sterile water. After, the electrode was immersed in $50 \mathrm{ml}$ of distilled sterile water containing $2 \mathrm{mg}$ of sterile ball glass ( $2 \mathrm{~mm}$ diameter) and was shaken with vortex for $5 \mathrm{~min}$ at maximal speed. At the end, the first and second volumes $(50 \mathrm{~mL} \times 2)$ were extracted to obtain $100 \mathrm{ml}$ of biofilm suspension and pour $0.1 \mathrm{ml}$ of biofilm suspension on nutrient agar plates. In nature happening microbes was already present on the plant roots at the time of replacement into the plant-MFC anode. Therefore, the plant-MFC contains a wide range of micro-organisms [11]. Similarly, the bacterial isolate exhibited maximum Cynodon dactylon activity was identified on the basis of morphological, cultural and biochemical characteristics [12]. 


\section{Results and Discussion}

Since, the world is looking up for the alternate method for production of renewable energy, the Cynodon dactylon was used as an energy source through bio-fermentation. Currently, it has been conventional that living plants can also generate electricity as they have the potential to from sun light also incorporate the circuits along with the electrodes; a value of 4.21 Volts was observed. This initial voltage reading was due to different factors such as exclusion of nutrients, discharge of oxygen, conducted through the parenchyma, scavenging the electrons composed at the anode or absence of adapted anodic rhizospheric bacteria [1]. The plants and microorganisms work in co-operation to create clean, safe and renewable energy. This process of electricity generation is non-destructive and hence it can be useful to the food crops like tomato plants, etc. while to obtain continues to be in existence. The promising results obtained from the present investigation were compiled under in this experiment along with the discussions for each of the physical, chemical and biological condition, further comparison were conducted to find out the maximum and minimum efficiency of electricity generation from the Cynodon dactylon. Plant microbial fuel cell pots gave a measure of a considerable amount of voltage to light up a small LED bulb generates from grass E-table as described by Kukshal, (2017) [9].

\subsection{Effect of Light Conditions}

Plant-MFCs systems are known for producing in-situ bioelectricity for the duration of the day. In order to analyze effect of sunlight on the electric output, the P-MFCs one pots was kept in light (L1) and shade conditions (S1) in the replicates of three for 15 days. Observations were recorded for both the parameters with the help of multimeter and it was found that for the samples brought from online and campus site, when paired up with and without plant (Figure 3.1). For L1 under light condition, the maximum generated potential of $0.62 \pm 0.05 \mathrm{~V}$ with plant and $0.33 \pm$ $0.05 \mathrm{~V}$ without plant (control) was observed on to 15 days respectively (Figure 3.1). Soil harbors microorganisms that contribute to the transfer and utilization of electrons released during the process of photosynthesis. The readings were recorded 0.63 to $3.12 \mathrm{~V}$ for 15 consecutive to study the effect of light on voltage and it was observed that voltage increased proportionally to the duration of sunlight as shown in graph 3.1. 

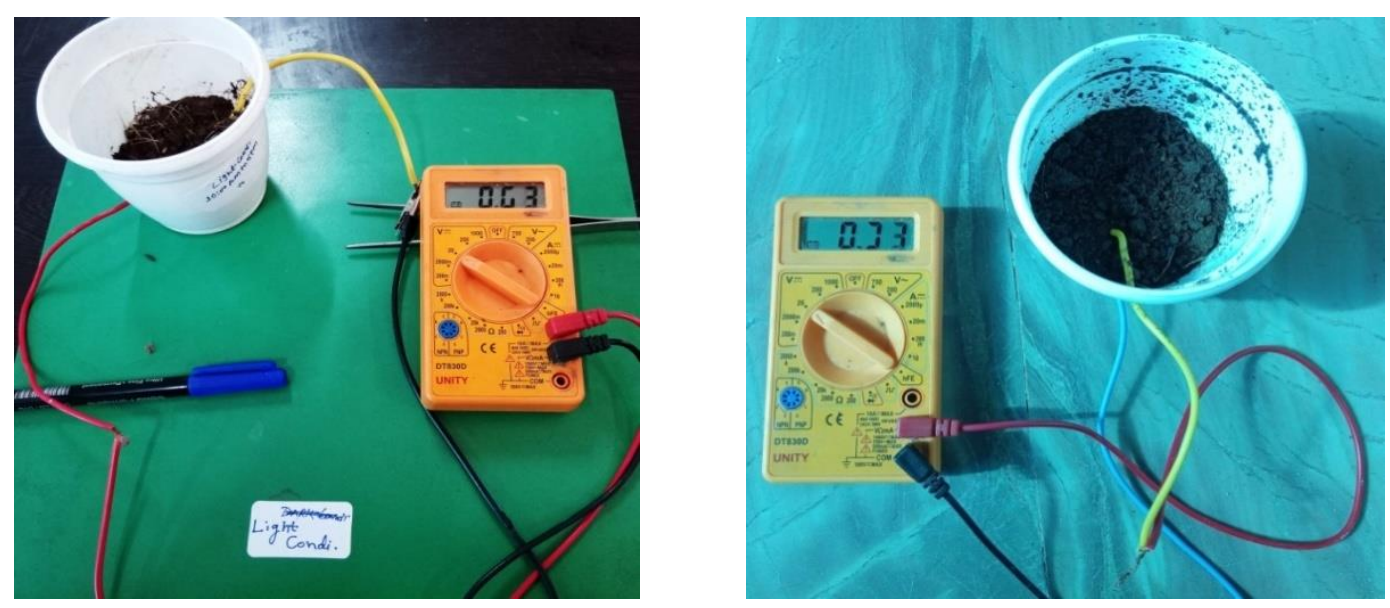

Figure 3.1. Observation recorded under light condition using multimeter

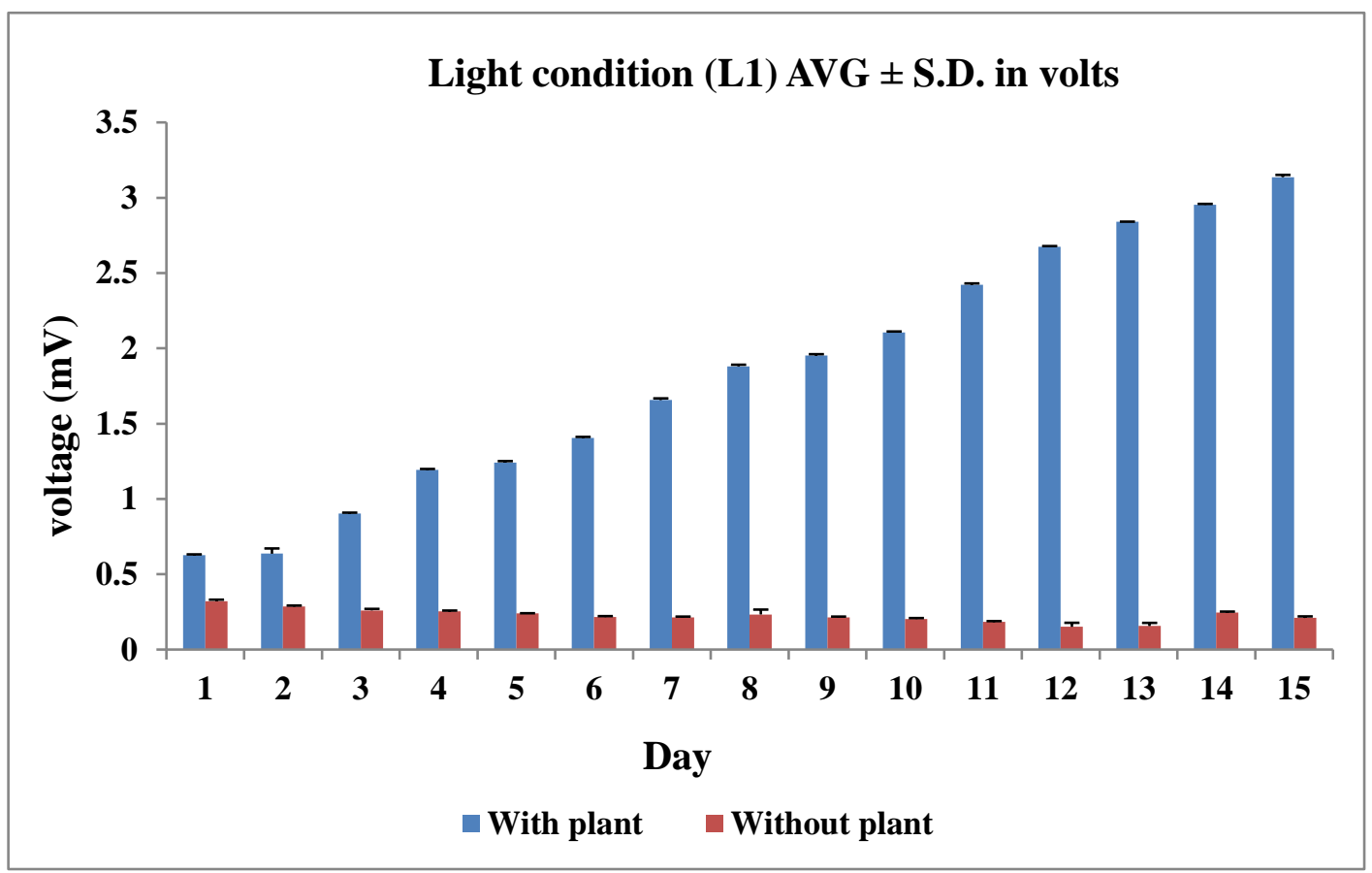


Figure 3.1. Graphical representation of electricity generation in volts from set up with plant and without plant under light condition.

\subsection{Effect of Shade Conditions}

The set up of S1 were placed under shade condition measurement of voltage for P-MFCs pots. They gave a good output, resulting in higher potential that was observed as $0.79 \mathrm{~V}$ at day 15 and $0.33 \pm 0.05 \mathrm{~V}$ without plant (control) was (Figure 3.2). The plants perform better in shade as grass are shade loving garden and when kept in direct sunlight, the damage to the green pigment chlorophyll was observed as the grass turns to dry. The absence of lignin in grass has left the cells unprotected against UV light. Chlorophyll is necessary for the process of photosynthesis and for the release electrons used in production of electricity. The potential generated was observed between $0.74-4.08 \mathrm{~V}$ in 15 days as shown in graph 3.2.

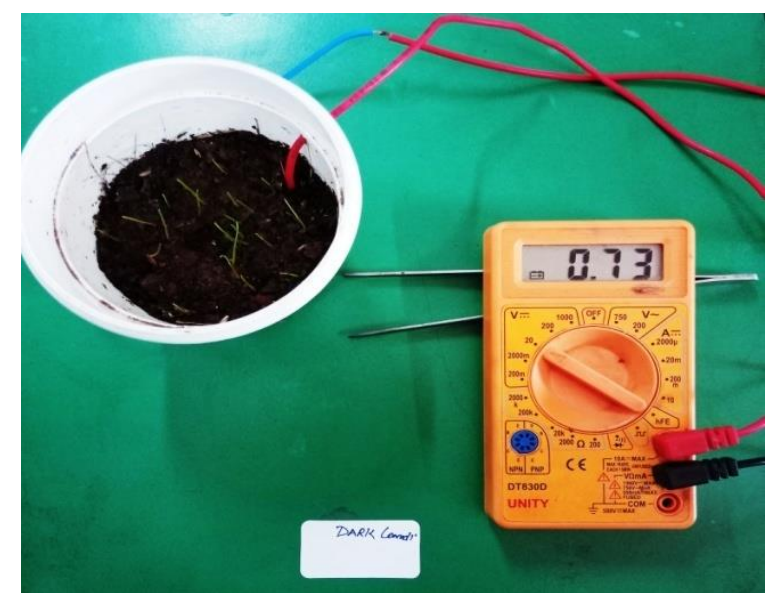

P-MFCs set-up with Cynodon dactylon

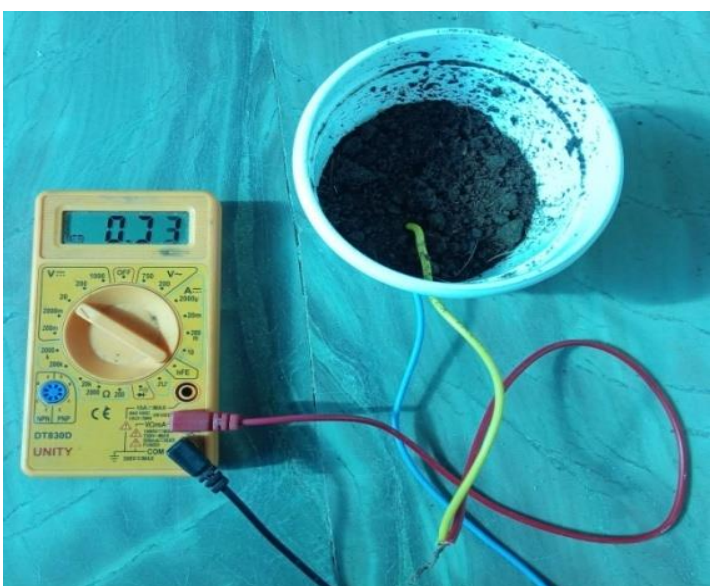

P-MFCs set-up without Cynodon dactylon

Figure 3.2. Observation recorded under shade condition using multimeter 


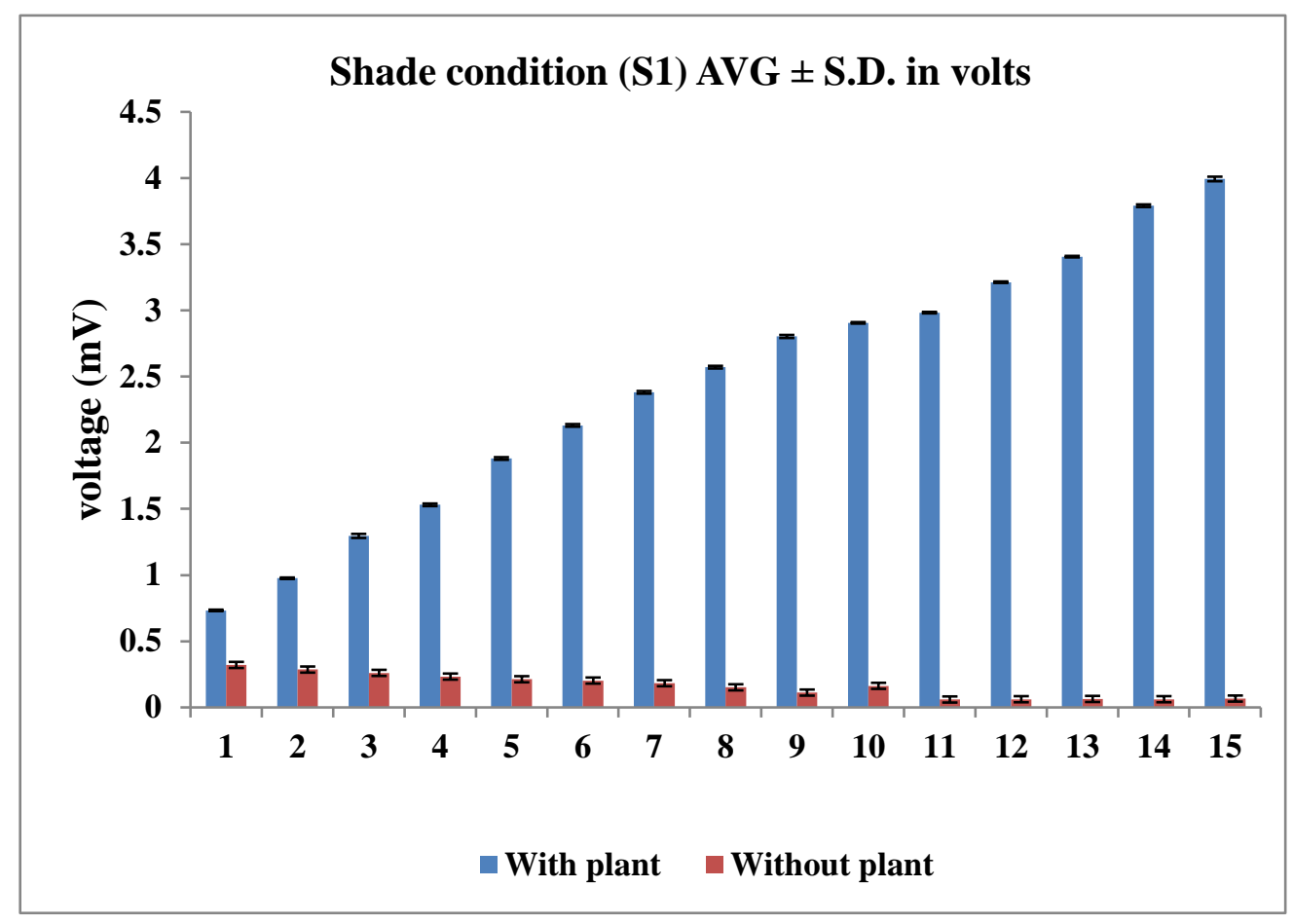

Figure 3.2. Graphical representation of electricity generation in volts from set up with plant and without plant under shade condition.

Table1. The Basics characteristics of soil

\begin{tabular}{|c|c|c|}
\hline S.NO. & Parameter & Quantity \\
\hline 1 & $\mathrm{pH}$ & 7.4 \\
\hline 2 & Total Nitrogen & $0.16 \%$ \\
\hline 3 & Total Organic Carbon & $0.18 \%$ \\
\hline
\end{tabular}

\subsection{To formulate electrical Grass E-table harness electricity by using P-MFCs}

To formulate electrical grass E-table harness electricity by using plant microbial fuel device exploits the electrons and protons generate by photosynthesis and metabolic activity. The Cynodon dactylon and rhizospheric soil containing bacterial material is placed inside one of electrode-containing chambers. The electrical currents produce through an external circuit. It 
showed the increasing trend up to 15 day and a good maintained result with values between $0.71-4.24$ Volts for 15 days as shown in figure 3.3.

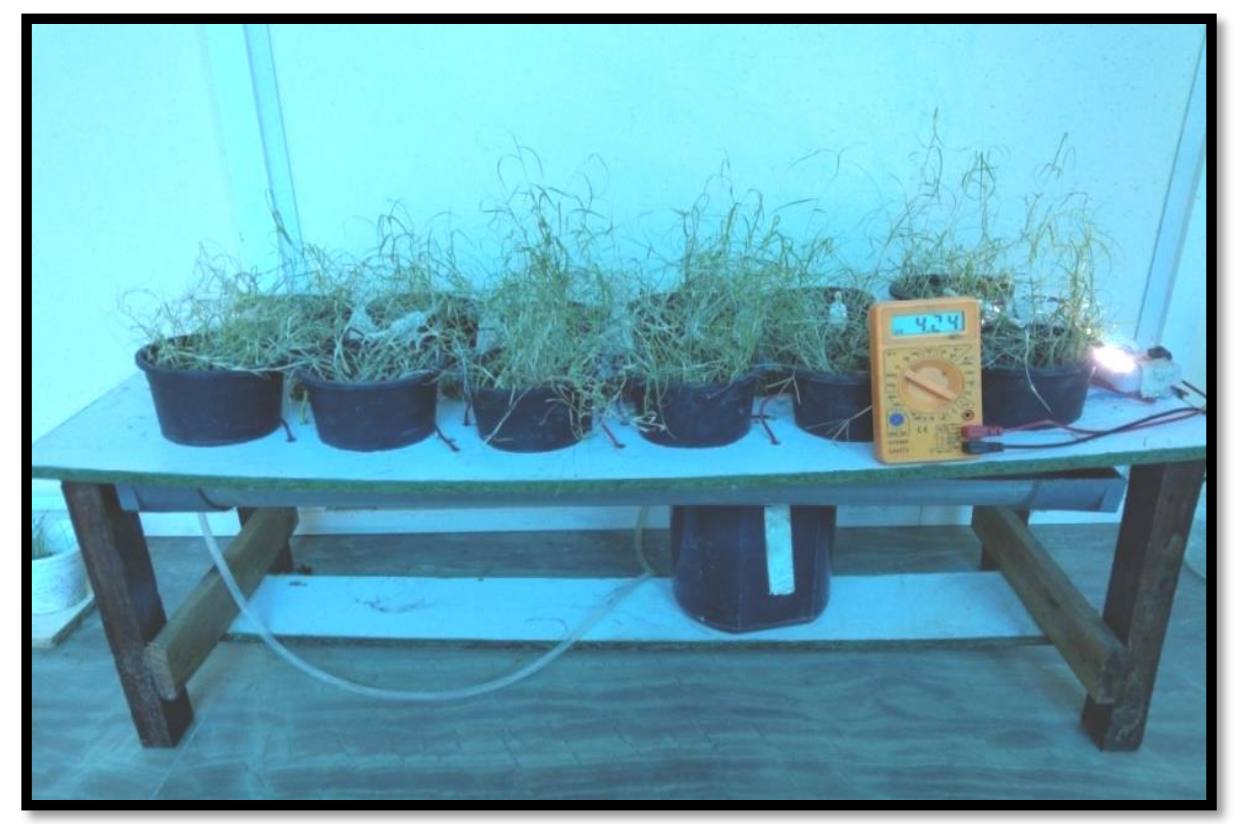

Figure 3.3. Showing the grass E-table in P-MFCs

\subsection{Identification of bacteria from anodic chamber in PMFCs set up}

Electricity generation in P-MFCs is based on the plant-roots loss of organic compounds and electrochemically active bacteria (EAB) oxidation of these organic compounds [13]. Approximately, 10 per $\mathrm{mL}$ of bacteria of isolates suspension per $\mathrm{mL}$ was obtained by counting the distinct colonies on nutrients agar. Microbiological analysis of the anodic biofilm and isolation of bacteria on selective media exposed the abundance of Gram-negative bacteria including two species belong to one species genus Enterobacteriacea family and another species Bacillus spp., [14]. A total of 9 morphologically different bacterial strain isolates were obtained from the rhizosphere soil of Cynodon dactylon grass. Similarly, Yahya et al., (2016) [15] had observed that the 5 isolates rhizospheric bacteria from Epipremnum aureum on the anode surface and identified on the basis of their morphological featured by using grams staining method according to methods described by Gram, (1884) [16]. The detailed results on the biochemical characterization of 
Cynodon dactylon from campus of R. D. University, Jabalpur isolates are documented in Table 2. In the IMViC all test are positive for both bacteria except voges Proskauer test i.e. negative test.

Table 2. Bacterial isolates from anodic chamber in P-MFCs set-up.

\begin{tabular}{|l|l|c|c|c|c|}
\hline S.No & $\begin{array}{c}\text { Plant-MFCs } \\
\text { setup }\end{array}$ & $\begin{array}{c}\text { Sample } \\
\text { Code }\end{array}$ & Location & Sample type & $\begin{array}{l}\text { Bacterial } \\
\text { Isolate }\end{array}$ \\
\hline \multirow{3}{*}{$\begin{array}{l}\text { Cynodon } \\
\text { dactylon }\end{array}$} & CD1 & Kasturi Nursery, & Rhizospheric & RSB-1 \\
& & & Jabalpur & soil & RSB-3 \\
& & & & & RSB-4 \\
& & & & & RSB-5 \\
& & & & & RSB-6 \\
& & & & & RSB-7 \\
& & & & & RSB-9 \\
& & & & & \\
\end{tabular}




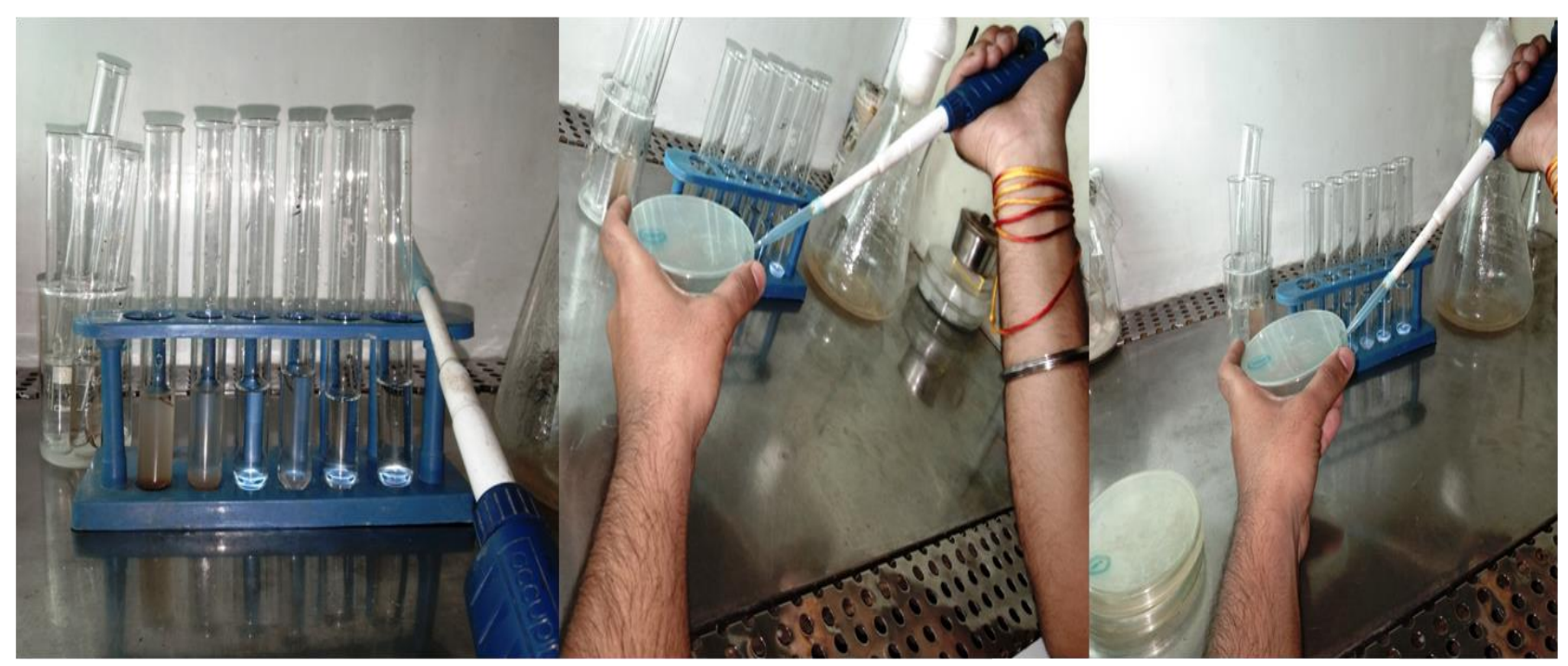

Serial dilution method

Pour plate method

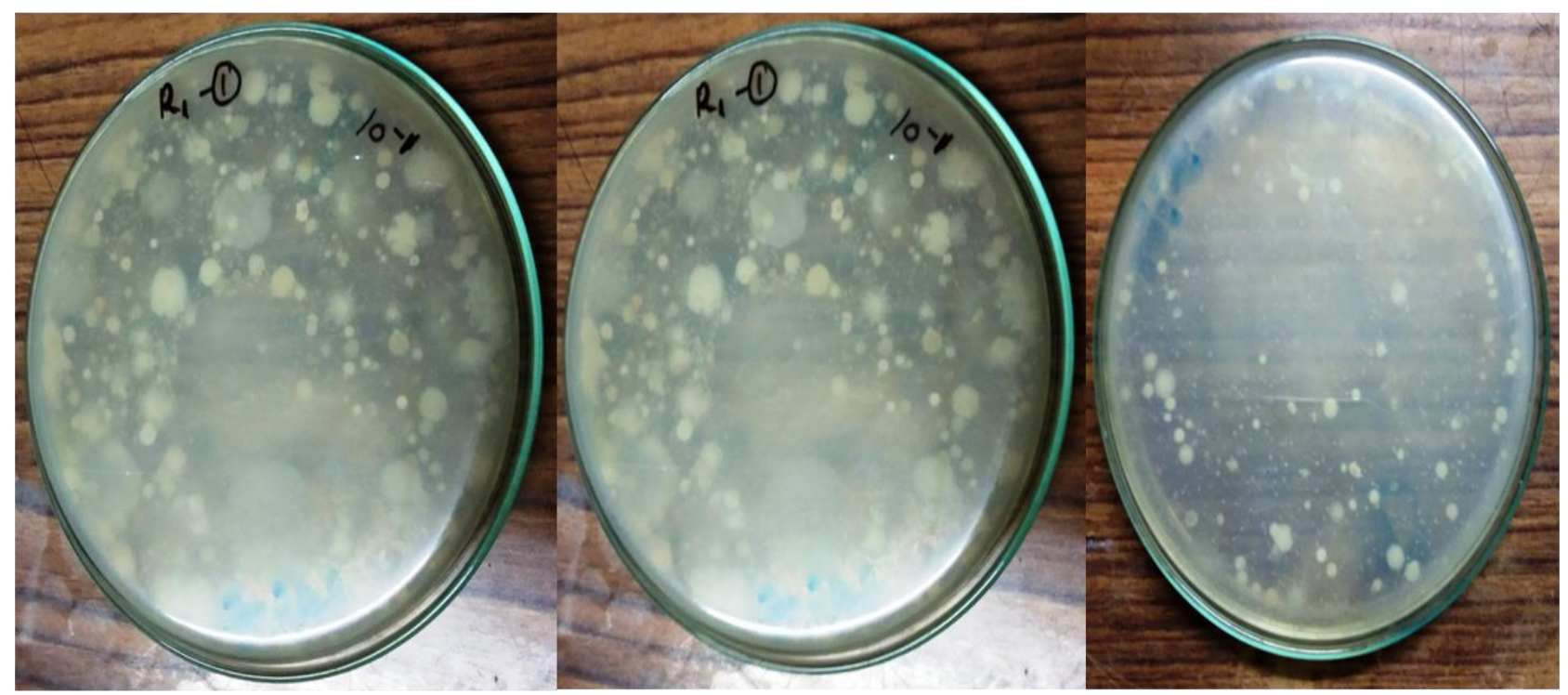

Figure 3.3. Showing the bacterial colonies

The list of microscopic observation of bacteria is documented in Table 3. In the other study, Dange et al., (2016) that the observed the grape rhizospheric bacteria was biochemical characterization were done using IMViC test, Gram staining, Catalase test and Urease test and others. Both Azotobacter spp and Pseudomonas spp both is Gram - ve in nature [17]. 
Table 3. Morphological and biochemical characteristics of bacterial strain isolated from Rhizospheric soil in P-MFCs setup.

\begin{tabular}{|c|c|c|c|c|c|c|c|c|c|c|c|c|c|c|c|c|c|c|}
\hline \multirow[t]{2}{*}{ Code } & \multicolumn{17}{|c|}{ Morphological and biochemical characteristics } & \multirow[t]{2}{*}{ Identified as } \\
\hline & $\begin{array}{l}\mathbf{1} \\
\mathbf{A}\end{array}$ & $\begin{array}{l}\mathbf{1} \\
\mathbf{B}\end{array}$ & 2 & 3 & 4 & 5 & 6 & 7 & 8 & 9 & 10 & 11 & 12 & 13 & 14 & 15 & 16 & \\
\hline $\begin{array}{c}\text { RSB- } \\
1\end{array}$ & + & $\mathrm{r}$ & + & + & + & - & + & + & - & - & + & + & - & - & + & - & + & Bacillus spp. \\
\hline $\begin{array}{c}\text { RSB- } \\
\mathbf{3}\end{array}$ & + & $\mathrm{r}$ & + & + & + & - & + & + & - & - & + & + & - & - & + & + & + & $\begin{array}{c}\text { Enterobacter } \\
\text { spp. }\end{array}$ \\
\hline $\begin{array}{c}\text { RSB- } \\
7\end{array}$ & + & $\mathrm{r}$ & + & - & - & + & - & + & + & - & - & + & + & - & - & + & + & $\begin{array}{c}\text { Pseudomonas } \\
\text { spp. }\end{array}$ \\
\hline $\begin{array}{l}\text { RSB- } \\
9\end{array}$ & + & $\mathrm{r}$ & + & + & - & - & - & - & - & - & - & + & + & + & + & + & + & Bacillus spp. \\
\hline $\begin{array}{c}\text { RSB- } \\
11\end{array}$ & - & $\mathrm{r}$ & + & + & + & - & - & - & + & - & - & - & - & - & - & - & - & E. coli \\
\hline
\end{tabular}

Note:+: Positive reaction;-: Negative reaction; 1A- Gram staining; 1B- $r=$ rod shape; 2- Motility; 3- Catalase; 4Oxidase; 5- Indole; 6- Methyl red; 7- Voges Proskauer; 8- Citrate; 9- $\mathrm{H}_{2} \mathrm{~S}$ (TSI); 10- Urease; 11- Glucose; 12Galactose; 13- Mannose; 14- Fructose; 15- Sucrose; 16- Maltose.

\section{Conclusion}

The research was carried out on the concept of generation of bioelectricity involving the Cynodon dactylon under different sets of conditions, which can be readily availed and easily created. The changeable used in this experiment for evaluating the bioelectricity generation potential of the Cynodon dactylon were exposure to light and shade condition. The method of plant microbial fuel cell has played a major part in bioelectricity generation as green plants harness solar energy and converts atmospheric carbon dioxide and soil water into organic compound. These compounds help the plant to grow during the photosynthesis, some of these organic compounds into the soil via plant roots. The soil microorganisms present in soil break down these organic compounds and liberate the by-product of electrons. These electrons at anode are transferred to cathode. Hence, the circuit gets completed finally produced of electricity. A bacterium is main role 
in producing of electricity through the use of plant rhizodeposits as a substrate under limited oxygen. Cynodon dactylon based P-MFCs; we are able to achieve the highest voltage of $0.63 \mathrm{~V}$ to 4.12 Volts on 15 days incubation. Further optimization in terms of area and electrode composition may be increasing amount of energy generated. This kind of technological innovation can be increasingly aggregated at the utilization of wetlands for power generation. It additionally finds an application in agricultural industry, as it gives in-situ bioelectricity creation without harmless for the plant.

\section{Acknowledgements}

The author is grateful to Vice Chancellor, Rani Durgawati University Jabalpur. Director, Bio-design Innovations Centre Rani Durgawati University Jabalpur, would like to thank Head, Department of Biological Science Rani Durgawati University, Jabalpur, India (M.P.). I would like to thankful M.H.R.D. New-Delhi, for permitting me to complete this research work.

Conflicts of Interests: The authors declare no conflict of interest.

\section{REFERENCES}

1. Schamphelaire, L.D.; Bossche, L.V.D.; Dang, H.S.; Hofte, M.; Hofte, N.; Rabaey, K.; Verstraete, W. Microbial fuel cells generating electricity from rhizodeposits of rice plants. Environ. Sci. \& Technol, 2008, 42, 3053-3058.

2. Bombelli, P.; Iyer, DMR.; Covshoff, S.; McCormick, A.J.; Yunus, K.; Hibberd, J.M.; Fisher, A.C.; Howe, C.J.; Comparison of power output by rice (Oryza sativa) and an associated weed (Echinochloa glabrescens) in vascular plant bio-photovoltaic (VP-BPV) systems. Appl. Microbiol. Biotechnol, 97, 2013, 429-438.

3. Guo, J.; Biophotovoltaics: generating electricity from moss. PCR Sprin. 2013, 6-9.

4. Helder, M.; Strik, D.P.B.T.B.; Hamelers, H.V.M.; Kuijken, R.C.P.; Buisman, C.J.N. New plant-growth medium for increased power output of the Plant-Microbial Fuel Cell. Bioresour. Technol. 2012, 104, 417-423.

5. Walker, K.; Burrows, G.; McMahon, L.; Bidgee, B. An identification guide to common native plant species of the south western slopes of New South Wales. Yarralu. Australi. Capita. Territo. Greeni. Austral. 2001, 82.

6. Jawre, A. Bio-Photovoltaic: the future of electricity with natural resource. Int. J. of Creati. Res. Though. 2018, 1, 1-13.

7. Olson, J.M. Photosynthetic in the Archean era. J. of photosyn, Res. 2006, 88, 109-117. 
8. Kumar, K.V.; Manmohan, K.; Sreelakshmi, P.M.; Gajalakshmi, S. Terracotta separator based plant microbial fuel cell for bioelectricity and catholyte production. Int. J. of Appli. Engineer. Reser, 2018, 13, 21, 14948-14955.

9. Kukshal, P. Bioelectricity generation through biological photovoltaic employing mosses. G.B. Pant University of Agriculture \& Technology Pantnagar, 2017, Uttrakhand, India.

10. Smil, V.; Leggett, A.J.; Philips, W.D.; Harper, C.L. Visions of discovery New light on Phy. Cosmolo. Conscious. Cambridge University Press, 2010.

11. Bombelli, P.; Dennis, J.R.; Felder, F.; Cooper, M.B.; Iyer, D.M.R.; Harrison, S.T.L.; Smith, A.J.; Harrison, C.J.; Howe, C.J. Electrical out-put of bryophyte microbial fuel cells system is sufficient to power a radio or an environmental sensor. Roy. Soci. Ope. Sci. 2016, 3, 160249.

12. Halder, D.; Mandal, S. Curd lactobacilli with probiotic potentiality. I Med Pub J. 2015, 6, $2 ;(8), 1-6$.

13. Potter, M.C. Electrical effects accompanying the decomposition of organic compound. Proc. 1911.

14. Tang, Y.W.; Ellis, N.M.; Hopkins, M.K.; Smith, D.H.; Dodge, D.E.; Persing, D.H. Comparison of phenotypic and genotypic techniques for identification of unusual aerobic pathogenic gram-negative Bacilli. J. of Clinic. Microbio. 1998, 36, 3674-3679.

15. Yahya, N.F.A.B.; Khilavi, D.N.; Ibrahim, N.B. Green electricity production by epipremnum aureum and bacteria in plant microbial fuel cell. J. of Adva. Res. in Appl. Sci. and Engineer. Technol. 2016, 5, 22-31.

16. Gram, C. The differential staining of Schzomycetes in tissue sections and in dried preparation. Forts Chritte, Der Medicin, 1884, 2, 185-189.

17. Dange, A.; Wayde, J.; Kumar, A.; Shinde, H.; Bhople, B.S.; Khan, A.J.; Sapkal, D.K.; Sahu, S.K. Biochemical and molecular characterization of grape rhizospheric microorganisms in Vani and Nandur Naka regions of Maharashtra. India. J. of Chem and Pharma Res. 2016, 8(3), 794-799. 